\title{
DIEL PATTERNS OF GROWTH AND DIVISION IN MARINE PICOPLANKTON IN GULTURE ${ }^{1}$
}

\author{
Stéphan Jacquet, ${ }^{2}$ Frédéric Partensky, Jean-François Lennon, and Daniel Vaulot \\ Station Biologique, Centre National de la Recherche Scientifique, Institut National des Sciences de l'Univers, and \\ Université Pierre-et-Marie-Curie, BP 74, 29682 Roscoff cx, France
}

The effect of a 12:12-h light:dark (LD) cycle on the phasing of several cell parameters was explored in a variety of marine picophytoplanktonic strains. These included the photosynthetic prokaryotes Prochlorococcus (strains MED 4, PCC 9511, and SS 120) and Synechococcus (strains ALMO 03, ROS 04, WH 7803, and WH 8103) and five picoeukaryotes (Bathycoccus prasinos Eikrem et Throndsen, Bolidomonas pacifica Guillou et Chrétiennot-Dinet, Micromonas pusilla Manton et Parke, Pelagomonas calceolata Andersen et Saunders, and Pycnococcus provasolii Guillard et al.). Flow cytometric analysis was used to determine the relationship between cell light scatter, pigment fluorescence, DNA (when possible), and the LD cycle in these organisms. As expected, growth and division were tightly coupled to the $\mathrm{LD}$ cycle for all of these strains. For both Prochlorococcus and picoeukaryotes, chl and intracellular carbon increased throughout the light period as estimated by chl fluorescence and light scatter, respectively. In response to cell division, these parameters decreased regularly during the early part of the dark period, a decrease that either continued throughout the dark period or stopped for the second half of the dark period. For Synechococcus, the decrease of chl and scatter occurred earlier (in the middle of the light period), and for some strains these cellular parameters remained constant throughout the dark period. The timing of division was very similar for all picoeukaryotes and occurred just before the subjective dusk, whereas it was more variable between the different Prochlorococcus and Synechococcus strains. The burst of division for Prochlorococcus SS 120 and PCC 9511 was recorded at the subjective dusk, whereas the MED 4 strain divided later at night. Synechococcus ALMO 03, ROS 04, and WH 7803, which have a low phycourobilin to phycoerythrobilin (PUB:PEB) ratio, divided earlier, and their division was restricted to the light period. In contrast, the high PUB:PEB Synechococcus strain WH 8103 divided preferentially at night. There was a weak linear relationship between the FALS max $_{\text {:FALS }}$ min ratio and growth rate calculated from cell counts $(r=0.83, n=11, P<0.05)$. Because of the significance of picoplanktonic populations in marine systems, these results should help to interpret diel variations in oceanic optical properties in regions where picoplankton dominates.

\footnotetext{
${ }^{1}$ Received 16 August 2000. Accepted 19 December 2000.

${ }^{2}$ Present address and author for correspondence: University of Bergen, Department of Microbiology, Jahnebakken 5, P.O. Box 7800, 5020 Bergen, Norway. E-mail nimsj@im.uib.no.
}

Key index words: cell cycle; diel rhythms; picoeukaryotes; Prochlorococcus; size; Synechococcus

Abbreviations: FALS, forward-angle light scatter; FCM, flow cytometry; PE: phycoerythrin; PUB:PEB, phycourobilin:phycoerythrobilin ratio; RALS, rightangle light scatter

In natural environments, phytoplankton are influenced by a variety of environmental factors, such as nutrient availability, temperature, mixing, and irradiance level. Among these, the daily alternation of light and darkness is undoubtedly a very important external stimulus. Diel periodicity has been documented for phytoplankton biomass and productivity (Prézelin 1992), nutrient uptake (Chisholm 1981), cell division (Nelson and Brand 1979), or gene expression (Liu et al. 1996). In oligotrophic areas, variations occurring at the daily scale are probably more relevant than those at monthly, seasonal, or annual scales. In particular, clear diel cycles of bulk oceanographic parameters related to phytoplankton such as beam attenuation or chl fluorescence have been reported in the tropical Pacific (Siegel et al. 1989), the North Atlantic (Gardner et al. 1995), and the equatorial Pacific (Claustre et al. 1999). Diel variations in optical properties also have been used to estimate oceanic primary production (Siegel et al. 1989).

The picoplanktonic fraction of marine phototrophs, Prochlorococcus, Synechococcus, and the picoeukaryotes, is now recognized to constitute the bulk of chl and carbon biomass in both intertropical and temperate oligotrophic areas (Li et al. 1992, Campbell and Vaulot 1993). Prochlorococcus and Synechococcus are closely related cyanobacteria with different sizes and light-harvesting antenna systems that enable them to occupy different ecological niches (for a review, see Partensky et al. 1999a). In contrast, picoeukaryotes constitute a much wider taxonomic assemblage, of which the diversity is only beginning to be revealed (Potter et al. 1997). Recent studies have shown that these picophytoplanktonic populations display clear diel patterns in the field.

Cell parameters such as DNA or carbon content and chl fluorescence of Prochlorococcus and Synechococcus are highly synchronized to the daily cycle, and physiological processes such as cell division take place every day during a very short time window in a variety of environments, including the equatorial Pacific, the tropical Atlantic, the Mediterranean Sea, or the Arabian Sea (e.g. Vaulot et al. 1995, Jacquet et al. 1998a). Phased cell division in the field is of particular interest 
because it allows assessment of population dynamics without the need to incubate samples. In particular, determination over a complete diel cycle in the variation of the percentage of cells in a terminal event of the cell cycle provides estimates of absolute growth rates (Carpenter and Chang 1988).

The causes of diel periodicity of cellular parameters are still poorly understood. Two major hypotheses have been advanced to explain the cell division cycle synchrony of phototrophic organisms: a direct control by light over a part of the cell cycle (Spudich and Sager 1980) or the existence of an entrainable biological clock whose diel periodicity can keep many cell processes phased over light:dark (LD) cycles (Edmunds and Adams 1981). Both mechanisms probably coexist. The latter hypothesis has been clearly demonstrated for Synechococcus (Sweeney and Borgese 1989) and its genetic basis uncovered (Ishiura et al. 1998). Nevertheless, sensors responsible for the entrainment of cell cycle remain to be identified.

In the present study, short-term variations $(\leq 1 \mathrm{~h})$ of cell concentration, light scatter, pigment fluorescence, and cellular DNA content were investigated by flow cytometry (FCM) using batch cultures acclimated to a 12:12-h light:dark (LD) cycle for a variety of photosynthetic prokaryotic and eukaryotic strains of picoplanktonic size. The main goals of this study were to determine 1) the specific oscillation patterns for the three major groups of picoplanktonic phototrophs, 2) the relationships between the patterns of the different cell parameters (size, pigment fluorescence, cell cycle) for a given phototroph, and 3) the relationship between the imposed LD cycle and the cellular patterns. These data should help to interpret patterns that have been observed in the field.

\section{MATERIALS AND METHODS}

Cultures. Characteristics of marine strains used in this study are reported in Table 1. Prochlorococcus strains SS 120 (CCMP 1375) and MED 4 (CCMP 1378) were obtained courtesy of Dr. L. Moore and Prof. S.W. Chisholm (MIT, Cambridge, MA). PCC 9511 is an axenic Prochlorococcus strain (Rippka et al. 2000). Syn- echococcus strains WH 8103 and WH 7803 were kindly provided by Drs. D. Scanlan (Warwick University, Coventry, UK) and B. Binder (University of Georgia, Athens, GA), respectively.

Growth conditions. Batch cultures of prokaryotes and eukaryotes were grown, respectively, in PCR-S11 (Rippka et al. 2000) and in K medium (Keller et al. 1987) made from filtered seawater aged for 2 months. Cultures were maintained in 500 to 1000 $\mathrm{mL}$ polyethylene Nalgene flasks (Bioblock, Illkirch, France) under blue light provided by four Daylight TLD $18 \mathrm{~W} / 82_{7}$ fluorescent bulbs (Philips), wrapped with "Moonlight Blue" filters (Lee Filters no. 183, Panavision, France). Light intensity was measured inside flasks filled with filtered seawater using a LICOR quanta-meter (Li-cor Ltd., Lincoln, NE) equipped with a $4 \pi$ spherical sensor. A 12:12-h LD cycle, with irradiance fixed at $25 \mu \mathrm{mol}$ quanta $\cdot \mathrm{m}^{-2} \cdot \mathrm{s}^{-1}$ during the light period, was applied to all strains. Average temperature was $20 \pm 1^{\circ} \mathrm{C}$. This temperature was suitable for near optimal growth for all studied organisms. Cultures were acclimated to these conditions for at least 2 weeks, and sampling began 3 to 5 days after the last dilution of the cultures (dilutions took place about once a week).

Culture sampling. Exponentially growing cultures were sampled every hour during $48 \mathrm{~h}$. Sampling was performed automatically using a computer-controlled peristaltic pump (Masterflex, Bioblock, Illkirch, France) and a custom-designed fraction collector (modified from Jacquet et al. 1998b; details can be found at http://www.sb-roscoff.fr/Phyto/SJ_sampler_98.html). The tubing system was equilibrated during 2 days before the experiment to eliminate possible toxic effects. Samples were kept until analysis or fixation in a large Plexiglas tank filled with circulating water at $4^{\circ} \mathrm{C}$ from a Minichiller system (Bioblock). Storage at $4^{\circ} \mathrm{C}$ for up to $10 \mathrm{~h}$ was previously shown to result in minimal effects on parameters measured by FCM, such as abundance, right-angle light scatter (RALS; a proxy for cell size), pigment fluorescence, and DNA histograms (Jacquet et al. 1998b).

Sample processing. Samples were divided into two aliquots. The first aliquot was analyzed fresh by FCM, generally after dilution with $0.2-\mu \mathrm{m}$ filtered seawater to avoid coincidence problems associated with high count rates. Efforts were made to reduce the lag interval between sampling and analysis for samples collected at night $(<8 \mathrm{~h})$. The second aliquot was fixed for 15 min with either glutaraldehyde for prokaryotes $(0.25 \%$ final concentration) or paraformaldehyde for eukaryotes ( $1 \%$ final), frozen in liquid nitrogen, and stored at $-80^{\circ} \mathrm{C}$ for delayed cell cycle analysis. Before analysis, this aliquot was thawed and incubated for $1 \mathrm{~h}$ at $37^{\circ} \mathrm{C}$ in the presence of $0.1 \mathrm{~g} \cdot \mathrm{L}^{-1}$ of a mixture of RNase A and B (R-4875 and R-5750, 1:1, w:w, Sigma, SaintQuentin Fallavier, France). After dilution (if necessary) with $0.2-\mu \mathrm{m}$ filtered seawater, samples were stained with SYBR Green I (Molecular Probes Inc., Eugene, OR, 1/10,000 final concentration) for at least $10 \mathrm{~min}$ (Marie et al. 1997).

TABLE 1. Characteristics of the different marine strains and species used in this study.

\begin{tabular}{|c|c|c|c|c|c|c|c|c|}
\hline Class & Genus and/or species & Strain & RCC & CCMP & $\begin{array}{l}\text { Unialgal/ } \\
\text { clonal }\end{array}$ & Origin & $\begin{array}{l}\text { Depth } \\
(\mathrm{m})\end{array}$ & Phenotype \\
\hline Cyanophyceae & Prochlorococcus & MED 4 & 153 & 1378 & $\mathrm{U}$ & NW Mediterranean Sea & 5 & Low chl $b / a$ \\
\hline- & $\begin{array}{l}\text { Prochlorococcus marinus } \\
\text { subsp pastoris }\end{array}$ & PCC 9511 & 168 & & C & & & Low chl $b / a$ \\
\hline- & Prochlorococcus marinus & SS 120 & 156 & 1375 & $\mathrm{U}$ & Sargasso Sea & 120 & High chl $b / a$ \\
\hline- & Synechococcus & ALMO 03 & 43 & & $\mathrm{U}$ & Alboran Sea & Surface & Low PUB:PEB \\
\hline - & Synechococcus & ROS 04 & 32 & & $\mathrm{U}$ & English Channel & Surface & Low PUB:PEB \\
\hline- & Synechococcus & WH 7803 & 28 & 1334 & $\mathrm{U}$ & N Atlantic & 25 & Low PUB:PEB \\
\hline- & Synechococcus & WH 8103 & 29 & & $\mathrm{U}$ & Sargasso Sea & Surface & High PUB:PEB \\
\hline Prasinophyceae & Bathycoccus prasinos & ALMO 02 & 113 & & $\mathrm{U}$ & Alboran Sea & Surface & \\
\hline Prasinophyceae & Micromonas pusilla & & 114 & 490 & $\mathrm{U}$ & n. a. & n. a. & \\
\hline Prasinophyceae & Pycnococcus provasolii & & 117 & 1203 & $\mathrm{U}$ & W Atlantic & 30 & \\
\hline Bolidophyceae & Bolidomonas pacifica & OLI31SA & 201 & & $\mathrm{U}$ & Equatorial Pacific & 15 & \\
\hline Pelagophyceae & Pelagomonas calceolata & & 100 & 1214 & $\mathrm{U}$ & Equatorial Pacific & 110 & \\
\hline
\end{tabular}

n. a., data not available; CCMP, Culture Collection of Marine Phytoplankton; PCC, Pasteur Culture Collection; RCC, Roscoff Culture Collection. 
Flow cytometric and data analysis. Samples were analyzed with a FACSort flow cytometer (Becton Dickinson, San Jose, CA) that provides two size-related parameters: the forward-angle light scatter (FALS) and RALS and three fluorescence signals referred to as "green" (530 $\pm 15 \mathrm{~nm})$, "orange" $(585 \pm 21 \mathrm{~nm})$, and "red" $(>650 \mathrm{~nm})$ fluorescence related, respectively, to DNA, phycoerythrin (PE), and chl contents of the cells. Cell concentration, FALS, RALS, PE, and chl fluorescences were acquired on fresh samples, and cell parameters were normalized to $0.95-\mu \mathrm{m}$ fluorescent beads (Polyscience, Inc., Warrington, PA). On SYBR Green I stained samples, green fluorescence from the DNA-dye complex was measured both on logarithmic and linear scales, as required for cell cycle analysis (Marie et al. 1997). It was not possible to obtain reliable cell cycle data for either the low phycourobilin:phycoerythrobilin (PUB:PEB) Synechococcus strains or for most eukaryotic species (with the notable exception of Bathycoccus prasinos) because of either poor dye penetration or interference with a large number of heterotrophic bacteria. Data were collected in list-mode files and then analyzed using the custom-designed freeware CYTOWIN (modified from Vaulot 1989; available at http://www.sb-roscoff. fr/Phyto/cyto.html). Cell cycle analyses were performed using MultiCYCLE (P.S. Rabinovitch, Phoenix Flow Systems, San Diego, CA).

Specific growth rate. Division rate was estimated from cell cycle data, when available, using the formula of Carpenter and Chang (1988):

$$
\mu_{\mathrm{CC}}=\frac{\sum_{i=1}^{n} \ln \left[1+f_{\mathrm{S}}\left(t_{i}\right)+f_{\mathrm{G}_{2}}\left(t_{i}\right)\right]}{n \times\left(T_{\mathrm{S}}+T_{\mathrm{G}_{2}}\right)} \times 24
$$

where $\mu_{\mathrm{CC}}$ is an estimate of the division rate $\left(\right.$ day $\left.^{-1}\right) ; n$ is the number of samples collected at fixed intervals during one subjective day; $T_{\mathrm{S}}+T_{\mathrm{G} 2}(\mathrm{~h})$ is the sum of the duration of $\mathrm{S}$ and $\mathrm{G}_{2}$ phases, computed as twice the delay between the peaks of cells in these phase $\left[2\left(t_{\mathrm{G} 2 \max }-t_{\mathrm{S} \max }\right)\right]$; and $f_{\mathrm{S}}\left(t_{i}\right)$ and $f_{\mathrm{G} 2}\left(t_{i}\right)$ are the fractions of cells in $\mathrm{S}$ and $\mathrm{G}_{2}$ phases at time $t_{i}$ (Table 2).

When no cell cycle data were available, growth rate was estimated from cell abundance using

$$
\mu_{\mathrm{NB}}=\frac{\operatorname{Ln}\left(N\left(t_{2}\right) / N\left(t_{1}\right)\right)}{\left(t_{2}-t_{1}\right)}
$$

TABLE 2. Growth rate calculated from cell number variation $\left(\mu_{\mathrm{NB}}\right)$ and from cell cycle $\left(\mu_{\mathrm{CC}}\right)$ over a diel cycle.

\begin{tabular}{llllll}
\hline \hline Strains or species & $\mu_{\mathrm{NB}}$ & $\mu_{\mathrm{CC}}$ & $T_{\mathrm{S}}$ & $T_{\mathrm{G}_{2}+\mathrm{M}}$ & $T_{\mathrm{g}}$ \\
\hline Prokaryotes & & & & & \\
$\quad$ Prochlorococcus MED 4 & 0.6 & 0.48 & 6.5 & 4.5 & 35 \\
Prochlorococcus PCC 9511 & 0.55 & 0.63 & 3 & 3 & 26 \\
Prochlorococcus SS 120 & 0.4 & 0.57 & 4 & 5 & 29 \\
Synechococcus ALMO 03 & 0.49 & n. a. & n. a. & n. a. & 34 \\
Synechococcus ROS 04 & 0.33 & n. a. & n. a. & n. a. & 50 \\
Synechococcus WH 7803 & 0.17 & n. a. & n. a. & n. a. & 98 \\
Synechococcus WH 8103 & 0.48 & 0.54 & 3.5 & 2.5 & 31 \\
Eukaryotes & & & & & \\
Bathycoccus prasinos & 0.23 & 0.49 & 6.5 & 2.5 & 34 \\
Bolidomonas pacifica & 0.91 & n. a. & n. a. & n. a. & 18 \\
Micromonas pusilla & 0.37 & n. a. & n. a. & n. a. & 45 \\
Pelagomonas calceolata & 0.5 & n. a. & n. a. & n. a. & 33 \\
Pycnococcus provasolii & 0.51 & n. a. & n. a. & n. a. & 33 \\
& & & & & \\
\hline
\end{tabular}

$T_{\mathrm{S}}$ and $T_{\mathrm{G}_{2}+\mathrm{M}}$ are the duration of active cell cycle phases $\mathrm{S}$ and $G_{2}$ as obtained from Carpenter and Chang's model (1988). Generation time $\left(T_{\mathrm{g}}\right)$, calculated using the formula $24 \times(\ln 2 / \mu)$, is estimated preferentially to $\mu_{\mathrm{CC}}$ when available otherwise from $\mu_{\mathrm{NB}}$. Division rates and durations are given in $d^{-1}$ and $h$ respectively. Cultures were grown in batch under 12:12-h LD cycle $\left(25 \mu \mathrm{mol}\right.$ quanta $\left.\cdot \mathrm{m}^{-2} \cdot \mathrm{s}^{-1}\right)$ at $20^{\circ} \mathrm{C}$. n. a., not available. where $N(t)$ is the average cell concentration $(n=3)$ at time $t$ and $t_{1}$ and $t_{2}$ correspond to the beginning and the end of a 24-h sampling period when no division occurs, that is, in early morn-
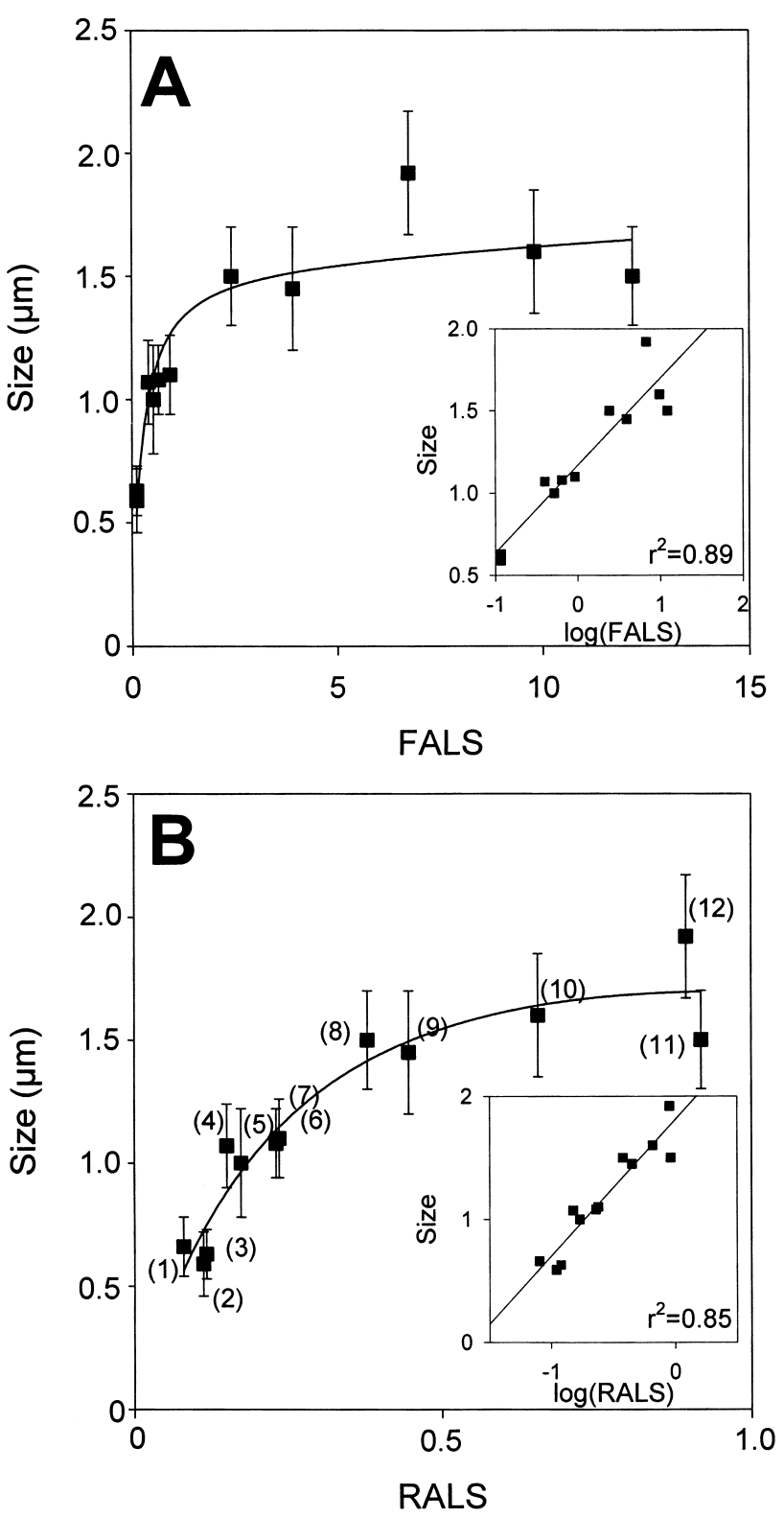

FIG. 1. Relationships between cell size (mean value and SD assessed by confocal microscopy and image analysis) and FALS (A) or RALS (B) for cultures of the picoplankters entrained by LD cycle sampled at "light on." Insets correspond to relationships between size and log of parameters (see Materials and Methods for equations). Cell size corresponds to average Feret diameter for prokaryotes and maximal length of the chloroplast for eukaryotes. FALS and RALS are normalized values to $0.95-\mu \mathrm{m}$-diameter spherical beads. Strain designation with number of measurements $(n)$ are as follows: 1, PCC $9511(n=$ 843); 2, SS $120(n=1342) ; 3$, MED $4(n=1382)$; 4, WH 8103 $(n=788) ; 5$, ROS $04(n=747) ; 6$, WH $7803(n=57) ; 7$, ALMO $03(n=122) ; 8$, Pycnococcus provasolii $(n=321) ; 9$, Bathycoccus prasinos $(n=362) ; 10$, Micromonas pusilla $(n=107)$; 11, Bolidomonas pacifica $(n=154)$, and 12, Pelagomonas calceolata $(n=293)$. 
ing when most of the cells are in the $G_{1}$ phase (Table 2). Dilution and pipetting errors and variation in the rate of the FCM sample delivery (due to possible temperature and hygrometric fluctuations) may introduce uncertainties in cell concentration estimates and, as a consequence, in estimates of $\mu_{\mathrm{NB}}$ (see also Discussion).

Calibration of FCM parameters by confocal microscopy. Cell size was determined with a confocal laser scanning microscope (CLSM, Fluoview, Olympus Optical Co., Tokyo, Japan) followed by image analysis. Cells were fixed with glutaraldehyde $(0.25 \%$ final concentration) and then filtered on $0.2-\mu \mathrm{m}$ pore size inorganic membrane filter disks (Anodisc, Whatman, Maidstone, UK). The filter disk was placed between a glass slide and a $22 \times$ 40 -mm coverslip in a $20-\mu \mathrm{L}$ mixture $(50 \%-50 \%)$ of normal PBS (Sigma) and bidistilled glycerol $(\mathrm{d}=1.26$, Fisher Scientific, Elancourt, France). The inverted CLSM was equipped with an argon-krypton continuous laser (model 643R-OLYM-A03, $20 \mathrm{~mW}$, Omnichrome, Melles Griot Laser Group, Carlsbad, CA). An Uplan $\mathrm{Fi} \times 60$ objective (numerical aperture, 1.25) was used with a pinhole size equal to the corresponding Airy diffraction disk. Laser light excitation ( 488 and $567 \mathrm{~nm}$ ) could be tuned at $6 \%$, $20 \%$, or $50 \%$ of maximum power. Particular care was taken not to saturate the fluorescence signal by modulating the laser power or the sensitivity of the photomultiplier. Cells were observed according to their natural pigment fluorescence. For prokaryotes, thylakoids surround the cell and cell size can be obtained directly from the red fluorescence image. For eukaryotes, the chloroplast does not occupy the whole cell; therefore, the cell outline was approximated by the smallest circle surrounding the chloroplast. In all cases, cell diameter was estimated as the Feret diameter $(d)$ given by the Image Tools software (version 1.27, T. Wilcox, available at http://www.uthscsa.edu/dig/ download.html) after appropriate calibration with a micrometer. Calibrated fluorescent beads $(0.95,1.98$, and $3.15 \mu \mathrm{m}$ in diameter) were used to establish the accuracy of the method. The following relationships were obtained for the picoplankton strains (Fig. 1):

$$
\begin{aligned}
& \mathrm{d}=0.53 \cdot \log (\text { FALS })+1.17\left(r^{2}=0.89, n=11, P<0.01\right) \\
& \mathrm{d}=1.10 \cdot \log (\text { RALS })+1.80\left(r^{2}=0.85, n=12, P<0.01\right)
\end{aligned}
$$

These equations were used to interpret the relative changes in FALS or RALS in terms of cell size changes (Table 3 ).

\section{RESULTS}

Prochlorococcus. Three strains of Prochlorococcus were examined: MED 4 and PCC 9511 (axenic), both characteristic from surface waters, and SS 120, characteristic from deep waters. The major increase in cell concentration occurred during the first part of the subjective night (Fig. 2, A, F, and K). During the light period, cell numbers remained quite stable or even decreased. Size-related parameters, FALS and RALS, were subjected to strong oscillations. Minimum and maximum relative values were recorded around the dark-light and light-dark transitions, respectively (Fig. 2, B, C, G, H, and L). The daily patterns for chl fluorescence signal (Fig. 2, D, I, and $\mathrm{M}$ ) paralleled those of scatter (i.e. a regular increase during the light period and a decrease at night) but with smaller amplitudes. Cell cycle was well phased to the LD cycle (Fig. $2, \mathrm{E}, \mathrm{J}$, and $\mathrm{N}$ ). It resembled that typically observed in eukaryotes, that is, a discrete DNA synthesis $\mathrm{S}$ phase separates two well-defined $G_{1}$ and $G_{2}$ phases. The percentage of cells in the $S$ phase of the cell cycle began to increase in the middle of the light period with a concomitant decrease in the percentage of cells in $G_{1}$.
Maxima in $\mathrm{S}$ were reached 3 to $5 \mathrm{~h}$ before darkness, and the burst of division as inferred from the peak of cells in $\mathrm{G}_{2}$ occurred early at night. A second minor peak of cells in $S$ phase was often recorded after the light-to-dark transition-but not for $\mathrm{G}_{2}$. Estimation of phase duration and division rate with Carpenter and Chang's model (1988) revealed in most cases longer duration for both $S$ and $G_{2}$ phases and a larger generation time for MED 4 than for the other two strains (Table 2).

Synechococcus. The Synechococcus strains analyzed were representative from both coastal and oceanic regions (Table 1). WH 7803, ROS 04, and ALMO 03 have a low PUB:PEB ratio, whereas WH 8103 has a high PUB:PEB ratio (not shown). Clear daily variations were observed for all cellular parameters (Fig. $3)$. The major increase in cell concentration was recorded in the second part of the light period for ALMO 03 (Fig. 3E), around the LD transition for ROS 04 and WH 7803 (Fig. 3, A and I), and restricted to the dark period for WH 8103, at least during the first diel cycle (Fig. 3M). FALS and RALS were clearly phased to the LD cycle, but the patterns differed significantly between strains. The maxima for light scatter were recorded during daylight for both ROS 04 and ALMO 03 and at the light-to-dark transition or slightly after (ca. $1 \mathrm{~h}$ after) for $\mathrm{WH} 7803$ and $\mathrm{WH}$ 8103, respectively. Scatter began to increase when the light was turned on except for ROS 04, for which RALS (but not FALS) was delayed to $2 \mathrm{~h}$ after the beginning of the light period (Fig. 3, B and C). Past the daily maximum, scatter patterns differed clearly between strains. In ROS 04 and ALMO 03, two phases were recorded: First RALS decreased until the end of the light period and then it remained constant during darkness. Such behavior also was recorded for FALS of ROS 04 but not for ALMO 03. For the two other strains, WH 7803 and WH 8103, both FALS and RALS decreased throughout the dark period.

$\mathrm{Chl}$ and PE fluorescence displayed clear diel patterns with an increase during most of the daylight period. Some differences appeared in the last part of the light period and at night. In WH 8103, both chl and PE fluorescence increased during daylight and then decreased regularly during the dark period until reexposure to light (Fig. 3P). For both ALMO 03 and WH 7803, chl and PE fluorescence remained nearly constant or even increased during darkness (Fig. 3, H and L). In ROS 04, chl fluorescence was characterized by a two-step decrease with a slope change at the LD transition, whereas PE fluorescence decreased rapidly and regularly all night long (Fig. 3D). This behavior suggested two different regulatory mechanisms for chl and PE. Reliable cell cycle data could only be obtained for WH 8103 (Fig. 3Q). Its cell cycle was similar to that of Prochlorococcus, with discrete phases. Entry in $\mathrm{S}$ occurred in the middle of the light period, and the maximum was recorded around the $\mathrm{LD}$ transition. The peak of cells in $G_{2}$ was recorded 3 to $4 \mathrm{~h}$ after that of $\mathrm{S}$ phase. The persistence of a significant fraction of 

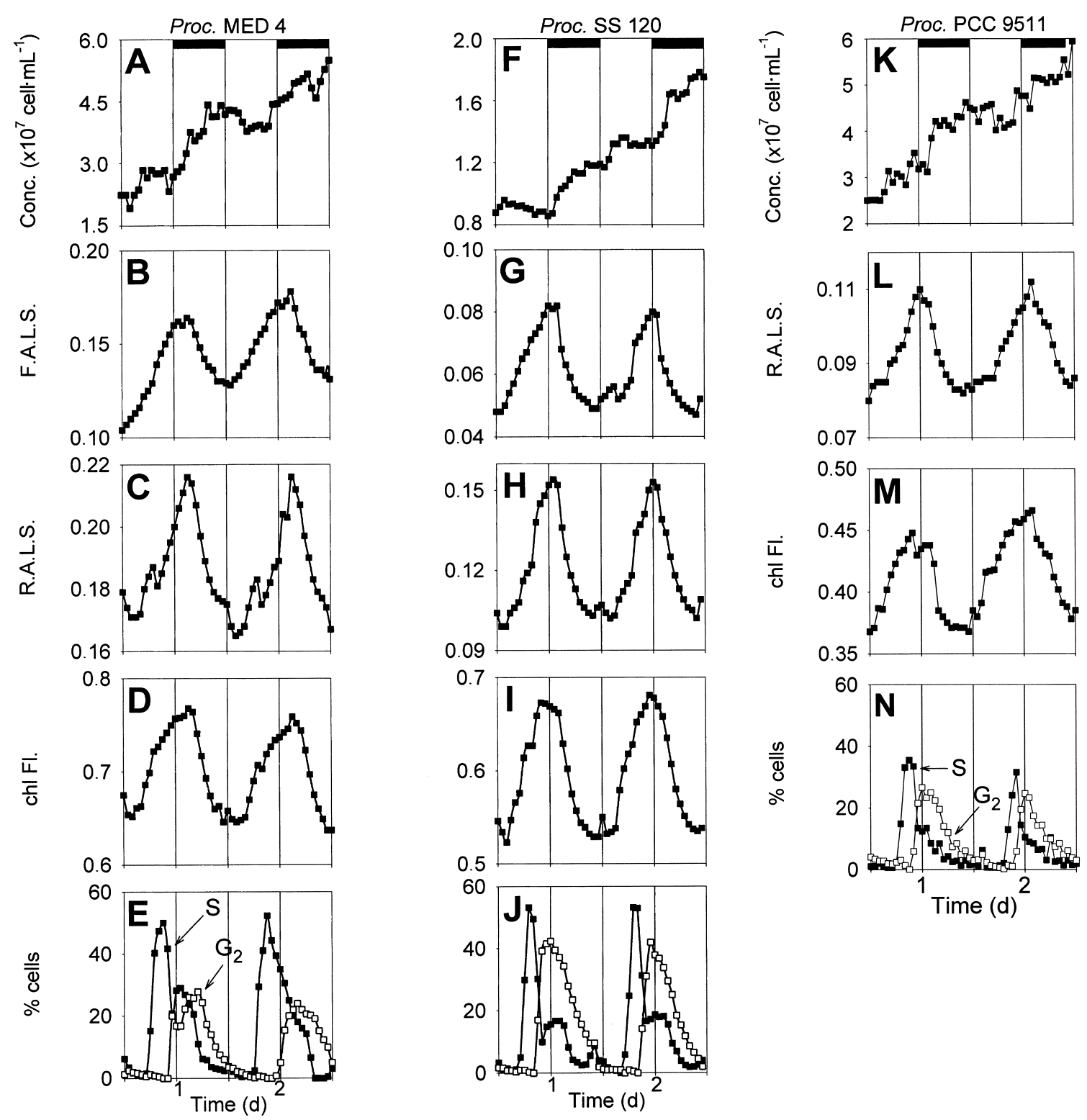

FIg. 2. Growth of Prochlorococcus strains MED 4, SS 120, and PCC 9511 under 12:12-h LD cycle with constant irradiance fixed at 25 $\mu \mathrm{mol}$ quanta $\cdot \mathrm{m}^{-2} \cdot \mathrm{s}^{-1}$. Cell concentration (A, F, and K), FALS (B and G), RALS (C, H, and L), chl fluorescence (D, I, and M), and percentage of cells in $\mathrm{S}$ and $\mathrm{G}_{2}$ phases of the cell cycle $(\mathrm{E}, \mathrm{J}$, and $\mathrm{N}$ ) are shown. Dark bars symbolize periods of darkness. No data were available for PCC 9511 FALS because of FCM problem.

cells in $\mathrm{G}_{2}$ throughout the LD cycle (except when $\mathrm{S}$ was maximum, Fig. $3 \mathrm{Q}$, but this is probably a computational artifact linked to cell cycle analysis, as $\mathrm{G}_{2}$ cells are difficult to discriminate from cells in late $S$ ) was in agreement with previous observations of low and persisting levels of dividing cells throughout the day (e.g. Binder and Chisholm 1995). Phase duration and growth rate estimation were quite similar to those recorded for PCC 9511 and SS 120, respectively (Table 2).

Picoeukaryotes. The picoeukaryote species used in this study were chosen to represent different marine systems (Table 1). Each species displayed clear diel patterns of FALS, RALS, and chl fluorescence (Fig.
4), and division occurred just before the subjective dusk. Minimum values for FALS, RALS, and chl fluorescence were recorded approximately at the dark-tolight transition and maximum values 2 to $3 \mathrm{~h}$ before darkness (Fig. 4). Chl fluorescence patterns evolved similarly to FALS and RALS, that is, there was a clear and regular increase during the daylight period and a decrease at night (Fig. 4). Patterns obtained for the cell cycle of $B$. prasinos were in agreement with results recorded for the other parameters (Fig. 4I). The fraction of cells in $\mathrm{S}$ increased $2 \mathrm{~h}$ after light onset and peaked in the middle of the light period (Fig. 4I). The $\mathrm{G}_{2}+\mathrm{M}$ peak occurred $4 \mathrm{~h}$ later. Phase duration 
TABLE 3. Maximum to minimum ratios of FALS and RALS over a diel cycle and corresponding size variations measured from the nonlinear relationships drawn on Figure 1.

\begin{tabular}{|c|c|c|c|c|c|c|}
\hline \multirow[b]{2}{*}{ Strains } & \multirow[b]{2}{*}{ FALS $_{\max } /$ FALS $_{\min }$} & \multirow[b]{2}{*}{$\Delta$ size-FALS (\%) } & \multirow[b]{2}{*}{$\mathrm{RALS}_{\max } / \mathrm{RALS}_{\min }$} & \multirow[b]{2}{*}{$\Delta$ size-RALS (\%) } & \multicolumn{2}{|c|}{ Size $(\mu \mathrm{m})$} \\
\hline & & & & & $\overline{\mathrm{AM}}$ & PM \\
\hline \multicolumn{7}{|l|}{ Prokaryotes } \\
\hline Prochlorococcus MED 4 & 1.6 & 12 & 1.3 & 14 & 0.63 & 0.72 \\
\hline Prochlorococcus PCC 9511 & & & 1.4 & 17 & 0.59 & 0.69 \\
\hline Prochlorococcus SS 120 & 1.7 & 14 & 1.5 & 23 & 0.66 & 0.82 \\
\hline Synechococcus ALMO 03 & 1.4 & 9 & 1.3 & 13 & 1.00 & 1.13 \\
\hline Synechococcus ROS 04 & 1.3 & 8 & 1.1 & 7 & 1.07 & 1.15 \\
\hline Synechococcus WH 7803 & 1.1 & 3 & 1.1 & 4 & 1.08 & 1.12 \\
\hline Synechococcus WH 8103 & 1.8 & 15 & 1.2 & 10 & 1.10 & 1.27 \\
\hline \multicolumn{7}{|l|}{ Eukaryotes } \\
\hline Bathycoccus prasinos & 1.5 & 12 & 1.2 & 11 & 1.50 & 1.67 \\
\hline Bolidomonas pacifica & 2.6 & 26 & 1.3 & 15 & 1.50 & 1.73 \\
\hline Micromonas pusilla & 1.8 & 16 & 1.3 & 12 & 1.45 & 1.68 \\
\hline Pelagomonas calceolata & 1.9 & 17 & 1.3 & 14 & 1.92 & 2.25 \\
\hline Pyconococcus provasolii & 1.9 & 17 & 1.5 & 20 & 1.60 & 1.92 \\
\hline
\end{tabular}

Size referred to as AM corresponds to that really measured at the light onset by confocal microscopy followed by image analysis and that referred to as PM is inferred from the RALS variation.

and growth rate estimation were in the same range as those reported for Prochlorococcus MED 4 (Table 2).

Relation between size increase and division rate. When cell division is restricted to a precise period of the day and cells are well phased, it has been shown that the relationship between maximum and minimum values of scatters can be empirically related to growth rates (e.g. Binder et al. 1996). All our data pooled together
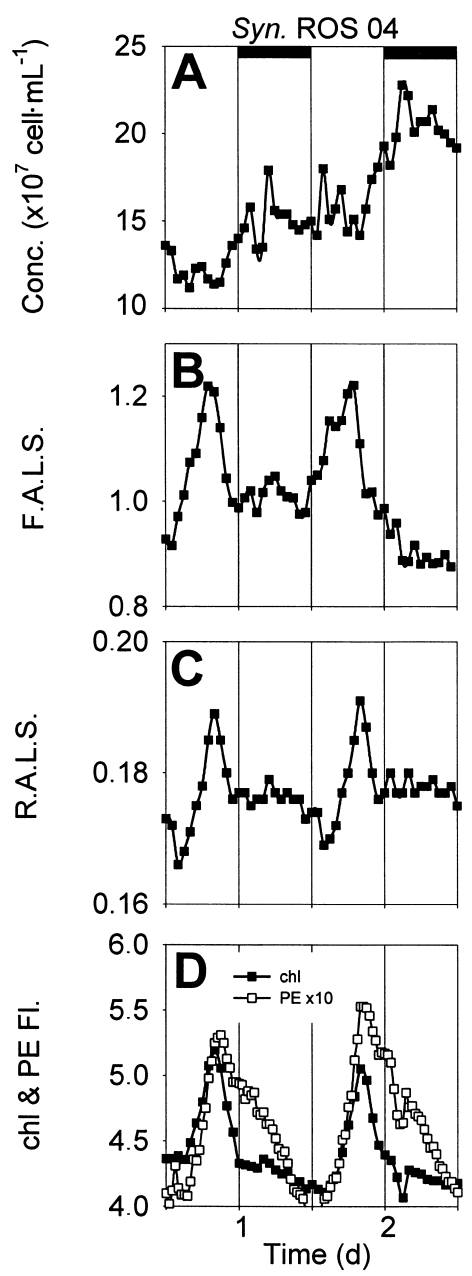
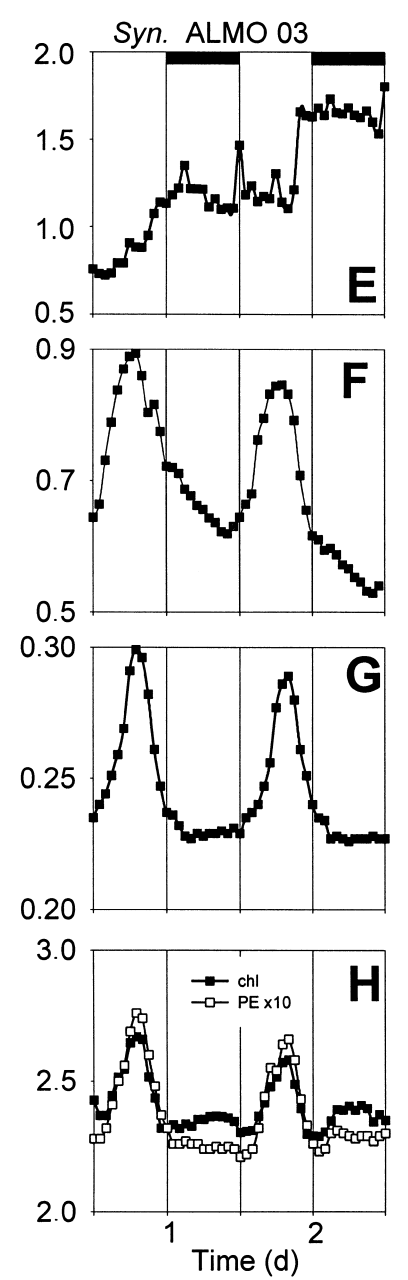

FIG. 3. Growth of Synechococcus strains ROS 04, ALMO 03, WH 7803, and WH 8103 under 12:12-h $\mathrm{LD}$ cycle with constant irradiance fixed at $25 \mu \mathrm{mol}$ quanta $\cdot \mathrm{m}^{-2} \cdot \mathrm{s}^{-1}$. Cell concentration $(\mathrm{A}, \mathrm{E}, \mathrm{I}$, and M), FALS (B, F, J, and N), RALS (C, G, K, and O), chl and PE fluorescence (D, H, L, and $\mathrm{P})$, and percentage of cells in $S$ and $G_{2}$ phases of the cell cycle of WH $8103(\mathrm{Q})$ are shown. Dark bars symbolize periods of darkness. 
yielded a linear relationship between $\mu \mathrm{NB}$ and FALS $_{\text {max }}$ : FALS $_{\text {min }}(r=0.83, n=11, P<0.01$; Fig. 5$)$ but not with RALS $_{\text {max }}:$ RALS $_{\text {min }}$ (data not shown).

\section{DISCUSSION}

Although synchronization of oceanic populations in the field by the natural diel cycle has been known for a long time (Gough 1905) and investigated in the 1970 s (e.g. Smayda 1975), it is only in the past 10 years that the ubiquity of this phenomenon has surfaced. Synchronization is especially easy to follow for picoplanktonic populations that can be monitored by FCM (e.g. Vaulot et al. 1995, DuRand and Olson 1996). However, to date, no laboratory study has been undertaken to compare patterns observed in major groups of picoplankton under similar experimental conditions.
The present work demonstrates that, broadly speaking, there is little variability in growth and division patterns across all picoplankton groups. In particular, increase in scatter and pigment fluorescence occurs almost only during the light period and is triggered by the onset of light. Scatter is a good proxy for cell size (Fig. 1) and cell carbon (Stramski et al. 1995, DuRand and Olson 1998), and therefore our data suggest that light is required for cell growth. This is especially visible in Synechococcus strains (e.g. Fig. 3G): Because division occurs relatively early and stops in the initial part of the dark period, scatter becomes constant early at night and increases again only at the dark-to-light transition. The major decrease in cell size is clearly linked to division. Once cells have divided (i.e. when no cells are left in $\mathrm{G}_{2}$ ) and remain in the dark, their size (or carbon content) continue to decrease, probably due
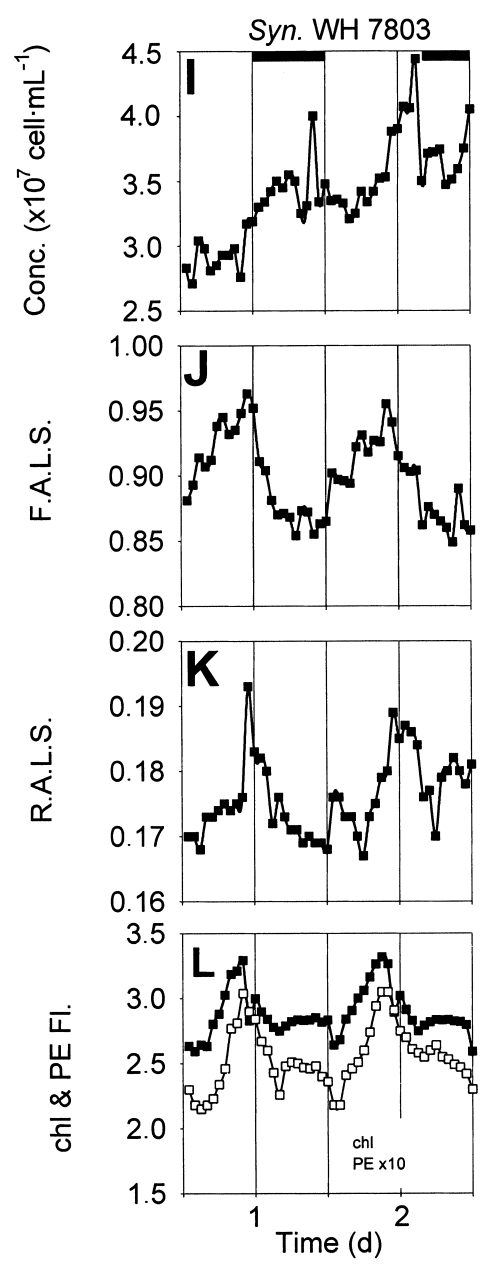
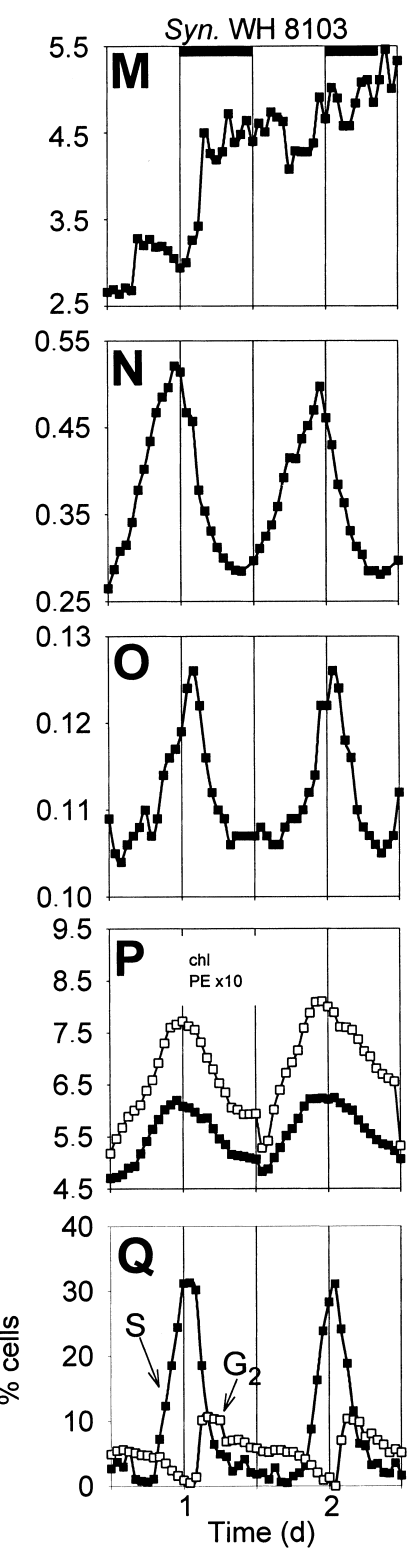

FIg. 3. Continued. 


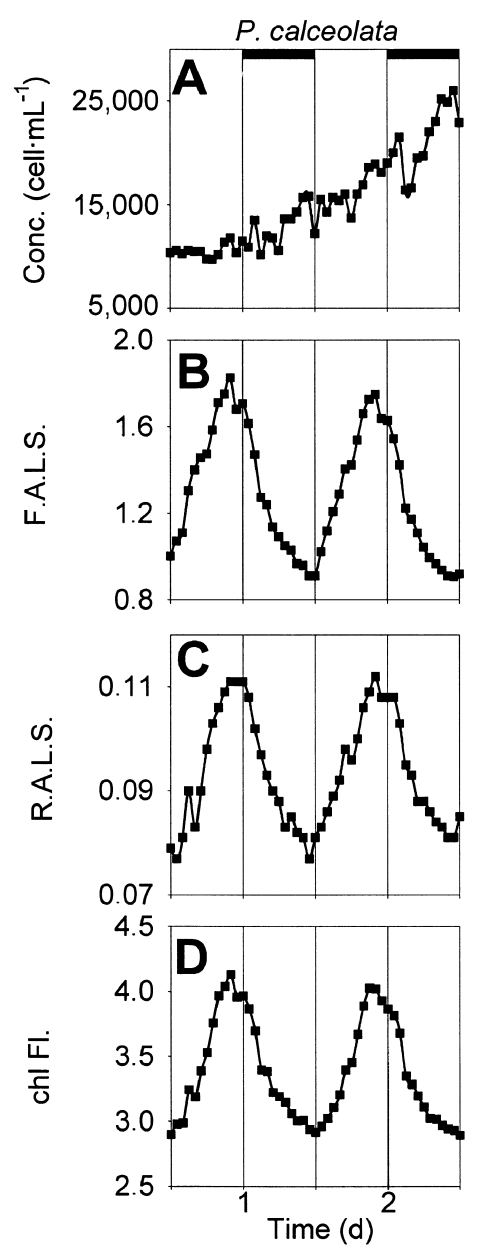

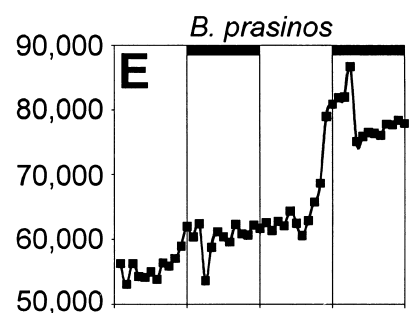
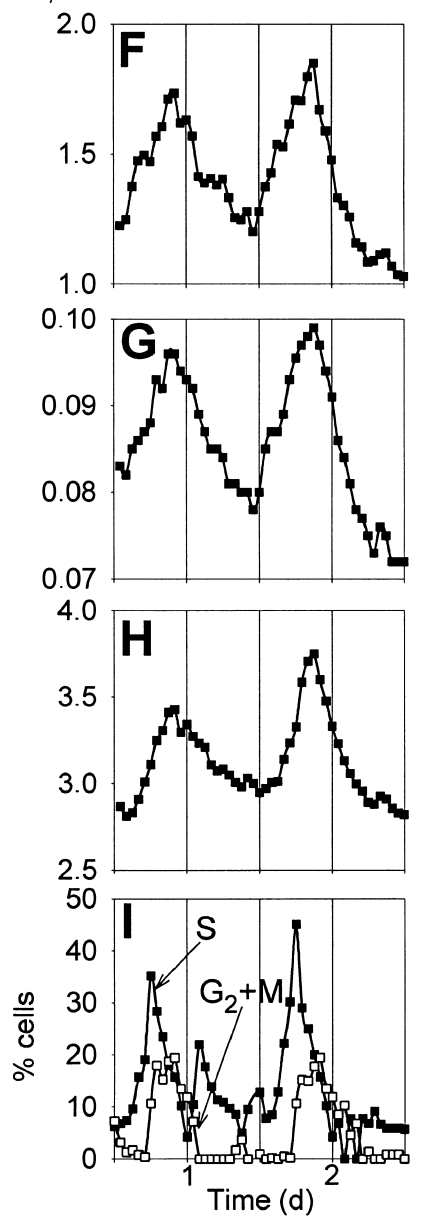

Fig. 4. Growth of eukaryotic species Pelagomonas calceolata, Bathycoccus prasinos, Micromonas pusilla, Pycnococcus provasolii, and Bolidomonas pacifica under 12:12-h LD cycle with constant irradiance fixed at 25 $\mu \mathrm{mol}$ quanta $\cdot \mathrm{m}^{-2} \cdot \mathrm{s}^{-1}$. Cell concentration (A, E, J, $\mathrm{N}$, and R), FALS (B, F, K, O, and S), RALS (C, G, L, $\mathrm{P}$, and $\mathrm{T})$, chl fluorescence (D, H, M, Q and $\mathrm{U})$, and percentage of cells in $S$ and $G_{2}$ phases (I) of the cell cycle of Bathycoccus are shown. Dark bars symbolize periods of darkness. to respiration. It is noteworthy that in Prochlorococcus, the scatter of the cells that are transferred to complete darkness keeps decreasing for more than 1 day after division has stopped but eventually reaches an asymptotic value (Jacquet et al. 2001). The behavior of pigment fluorescence is in general parallel to that observed for scatter. As in our experiments, the light intensity used was probably not inhibitory (e.g. for Prochlorococcus) - no quenching occurred as observed, for example, in oceanic surface populations (Vaulot and Marie 1999) —and red fluorescence was probably mainly related to cell pigment content. Our data suggest that pigment synthesis and cell growth are probably tightly linked.

For all the organisms we examined, both prokaryotic and eukaryotic, the DNA replication phase $S$ was always restricted to a fraction of the cell cycle, delim- ited by well-defined $\mathrm{G}_{1}$ and $\mathrm{G}_{2}$-like phases. In particular, we never observed continuous DNA replication or multiple copies of the chromosome, as reported by Binder and Chisholm (1995) in one of the strains we examined: WH 7803. This difference could either be due to our culture conditions or to actual genetic differences between the two cultures, although they have the same strain name. In all strains, division was restricted to the day-night transition, except for some Synechococcus strains for which it occurred earlier (see below). Interestingly, two successive $\mathrm{S}$ maxima occurred in some Prochlorococcus strains (Fig. 2), a phenomenon previously observed (Shalapyonok et al. 1998). Here, the second round of replication could be due to a partial asynchrony of the population, with two cohorts that replicate DNA slightly out of phase. Alternatively, some cells could undergo two successive 

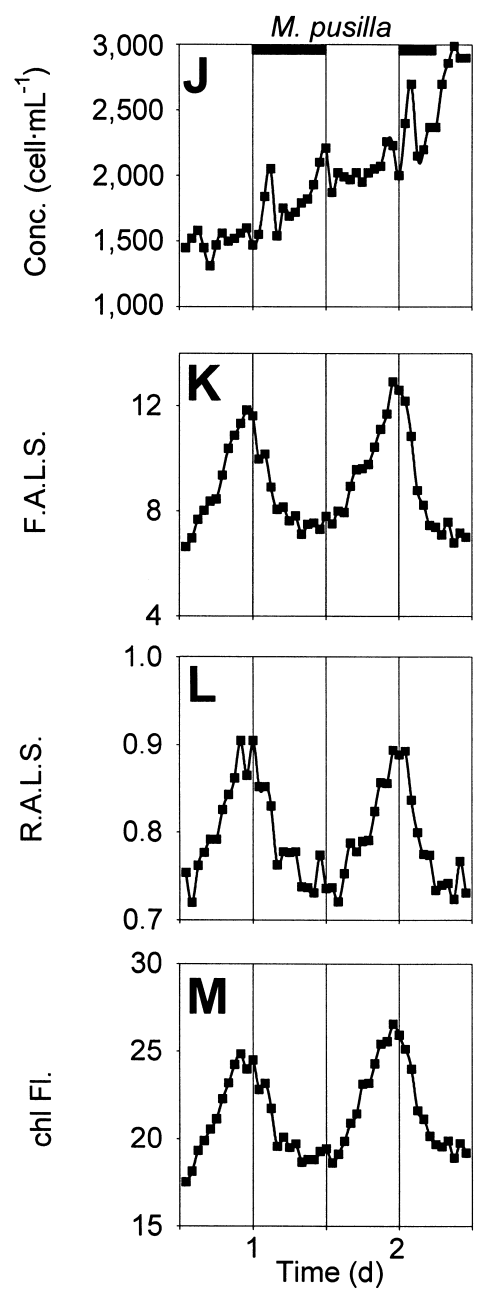
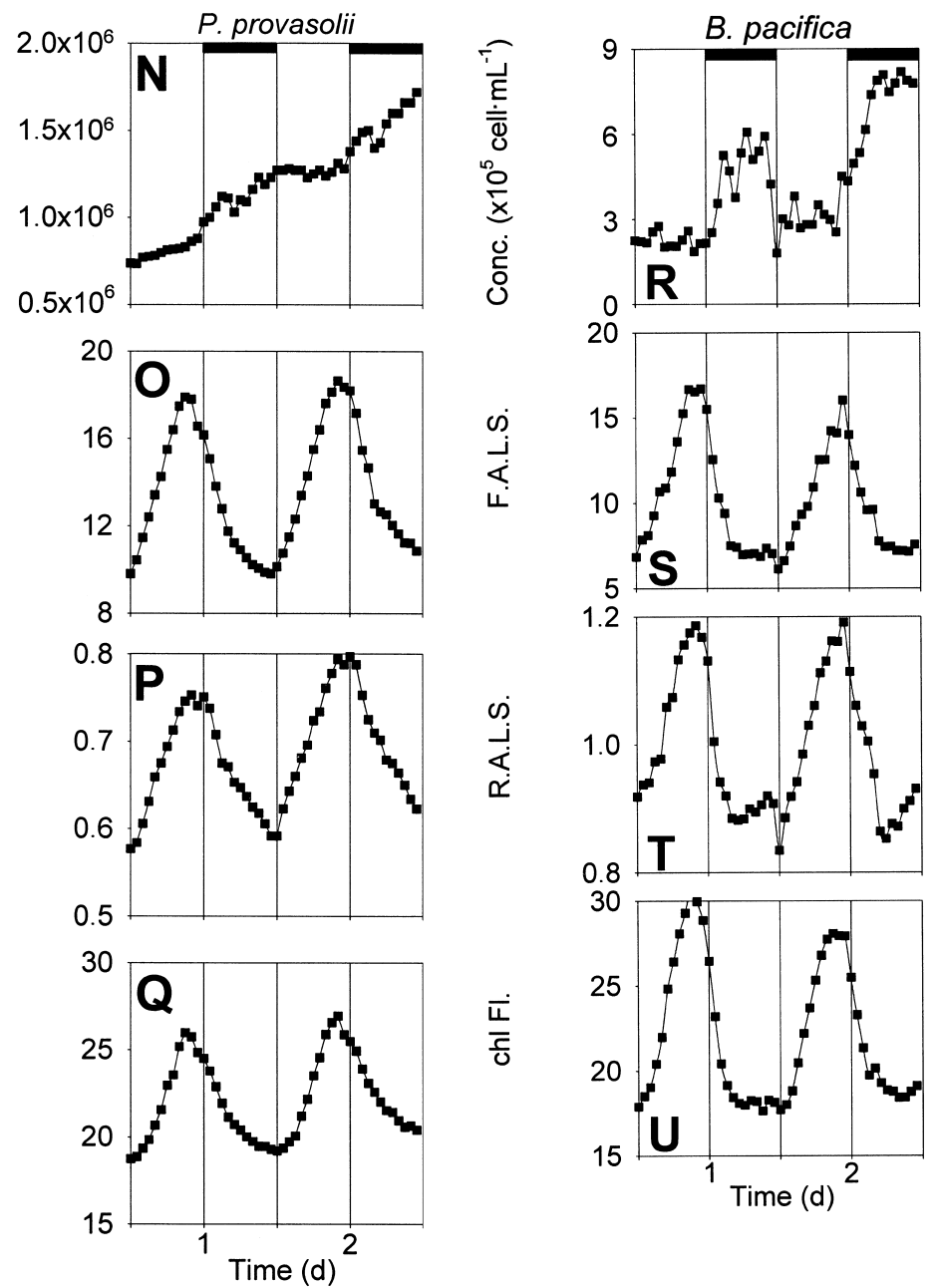

FIg. 4. Continued.

rounds of DNA replication and division despite the fact that the overall population divided less that once a day, in contrast to what was observed by Shalapyonok et al. (1998).

The absence of very marked differences in growth and division patterns in picoplankton is surprising in view of the large phylogenetic range examined from cyanobacteria to Prasinophytes, Pelagophytes, and Bolidophyceae. In fact, among larger sized groups such as diatoms or dinoflagellates, much more variability is observed; some diatoms, for example, divide early in the day (Chisholm 1981). Synechococcus was the only picoplankter exhibiting a wide range of phasing for division (see also Table 6). For this genus, timing of division appears linked to accessory pigment content of the cells because low and high PUB:PEB strains divided during daylight and at night, respectively. It is also noteworthy that within the low PUB:PEB, coastal strains ROS 04 and ALMO 03 divided earlier than the more oceanic representative $\mathrm{WH} 7803$. These results are consistent with the fact that these genetically distinct strains may respond differently to their light en- vironment (Binder and Chisholm 1995). For example, different strains may require different integrated light doses to initiate the division processes. Another unique characteristic of the low PUB strains was to stop division almost immediately in the dark, as suggested by the sudden change in the slope of scatters (see ROS 04 and ALMO 03 in Fig. 3, B, C, and G). There could be in these low PUB strains an absolute need of light to complete division as suggested by earlier studies (Armbrust et al. 1989, Binder and Chisholm 1995), in contrast to most photosynthetic unicells such as Prochlorococcus or diatoms (Vaulot et al. 1986, Jacquet et al. 2001). Clearly, more experimental work is needed to test a potential relationship between phenotypic characters such as the PUB:PEB ratio and the timing of cell division.

How do these patterns in culture compare with those observed in the field? Tables 4, 5, and 6 show a striking similarity between the two sets of observations. Broadly speaking, Synechococcus divides in general first (and displays more variability), followed by Prochlorococcus, followed by eukaryotes (the dephasing 


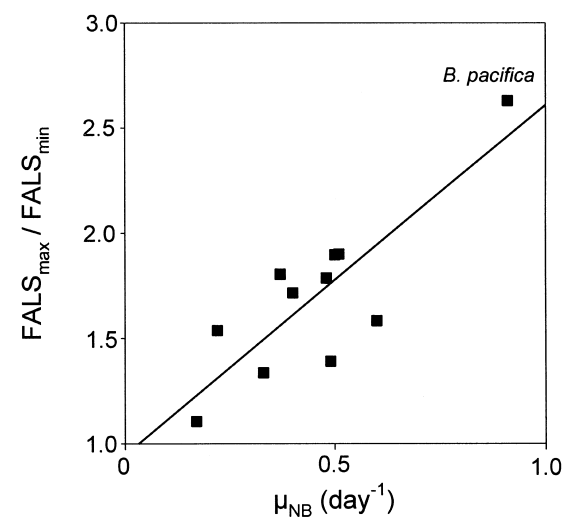

FIG. 5. Relationship between the ratio FALS ${ }_{\max }:$ FALS $_{\min }$ and growth rate calculated from cell numbers $\left(\mu_{\mathrm{NB}}\right)(r=0.83$, $n=11, P<0.01)$.

between the latter two is only slight). Synechococcus constitutes the most original case because it displays more variability than the others, both in culture and in the field. This organism divides earlier during the day in coastal waters (e.g. off Woods Hole or in the Chesapeake Bay), which matches well with cultures, because strains without PE or with a low PUB:PEB ratio are characteristics of coastal waters (Olson et al. 1990, Wood et al. 1998), although the PUB:PEB ratio is probably a polyphyletic trait (Toledo et al. 1999). In contrast, late division, that is, after dusk, has been observed in the Mediterranean Sea. In the latter case, however, nutrient limitation may play a key role. Vaulot et al. (1996) showed that in the Mediterranean Sea, $\mathrm{P}$ depletion induced a clear retardation of DNA replication and therefore of cell division. Two other factors that also play a role for field surface populations are photoinhibition and excess UV radiation, both probably causing a delay in DNA replication and cell division (e.g. Jacquet et al. 1998a). Genetic variability may explain some differences between field and culture behavior, especially for eukaryotes for which cultured strains probably represent only a very small fraction of oceanic species (e.g. Moon-van der Staay et al. 2000).

Our study finally establishes that division rate can be roughly estimated from the ratio of the maximum to minimum forward scatter for a wide range of picoplanktonic species (Fig. 5), as demonstrated earlier for specific populations (e.g. Binder et al. 1996, Vaulot and Marie 1999). Such estimates should be useful because, for many field populations, scatter is easy to measure by FCM, whereas cell cycle analysis can be impossible due to either low cell concentration, interference with bacteria, or poor dye penetration into cells.

Supported by contracts MAS3-CT95-0016 (MEDEA) and CT970128 (PROMOLEC) from the European Commission, by the French PROSOPE program, and by a doctoral fellowship from the Ministère de la Recherche et de l' Enseignement Supérieur granted to S. Jacquet. Financial support for the confocal microscope was provided by the following institutions: Conseil Général du Finistère, Conseil Régional de Bretagne, and Fondation EDF. We are grateful to Rosi Rippka (Pasteur Institute, Paris, France), who provided the axenic strain of Prochlorococcus PCC 9511, and to Sandrine Boulben and Daniel Poher (Station Biologique, Roscoff, France) for their technical assistance. Alexandra Worden (University of Georgia, Athens, GA) and two anonymous reviewers are acknowledged for their critical reading and improvements of a former version of this manuscript.

TABLE 4. Timing of division cycle for Prochlorococcus under LD in culture and in the field.

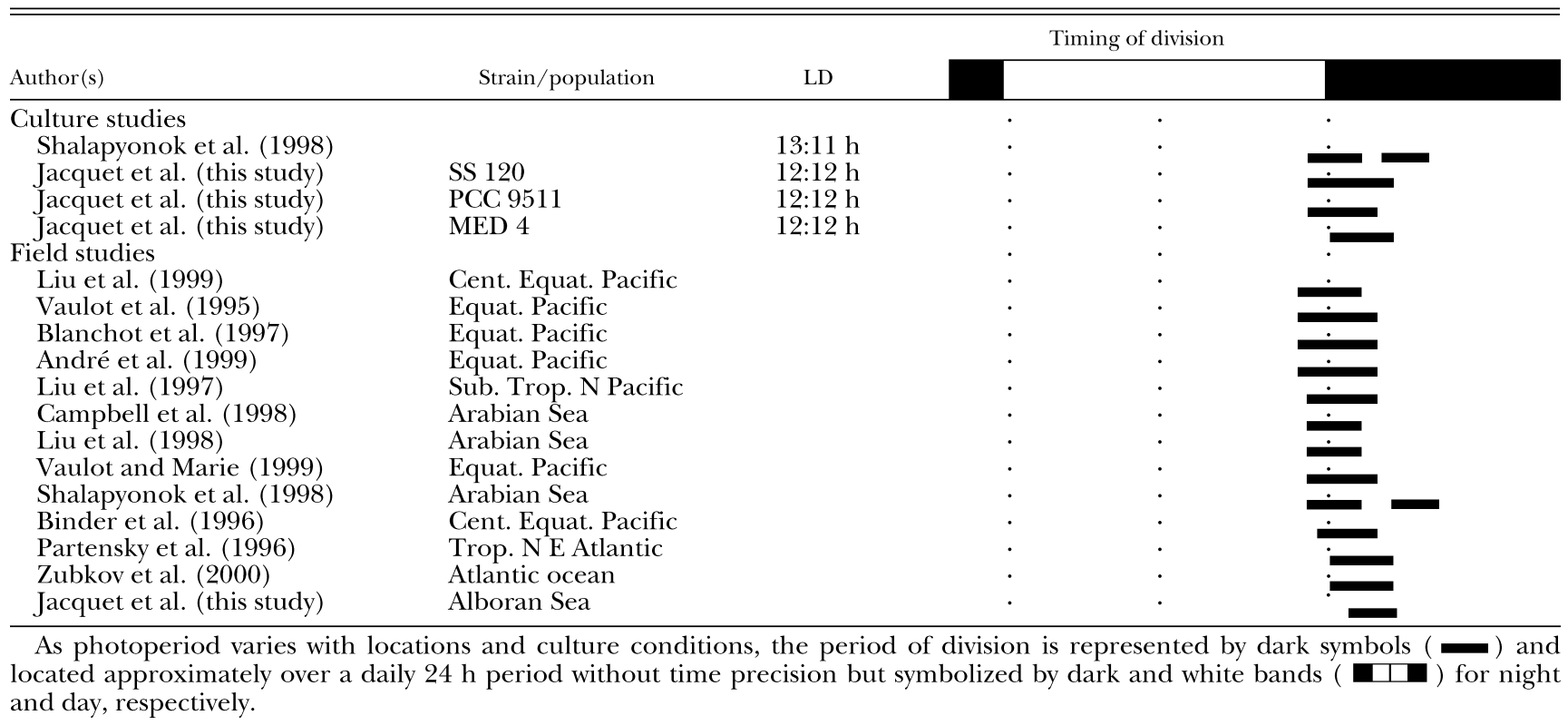




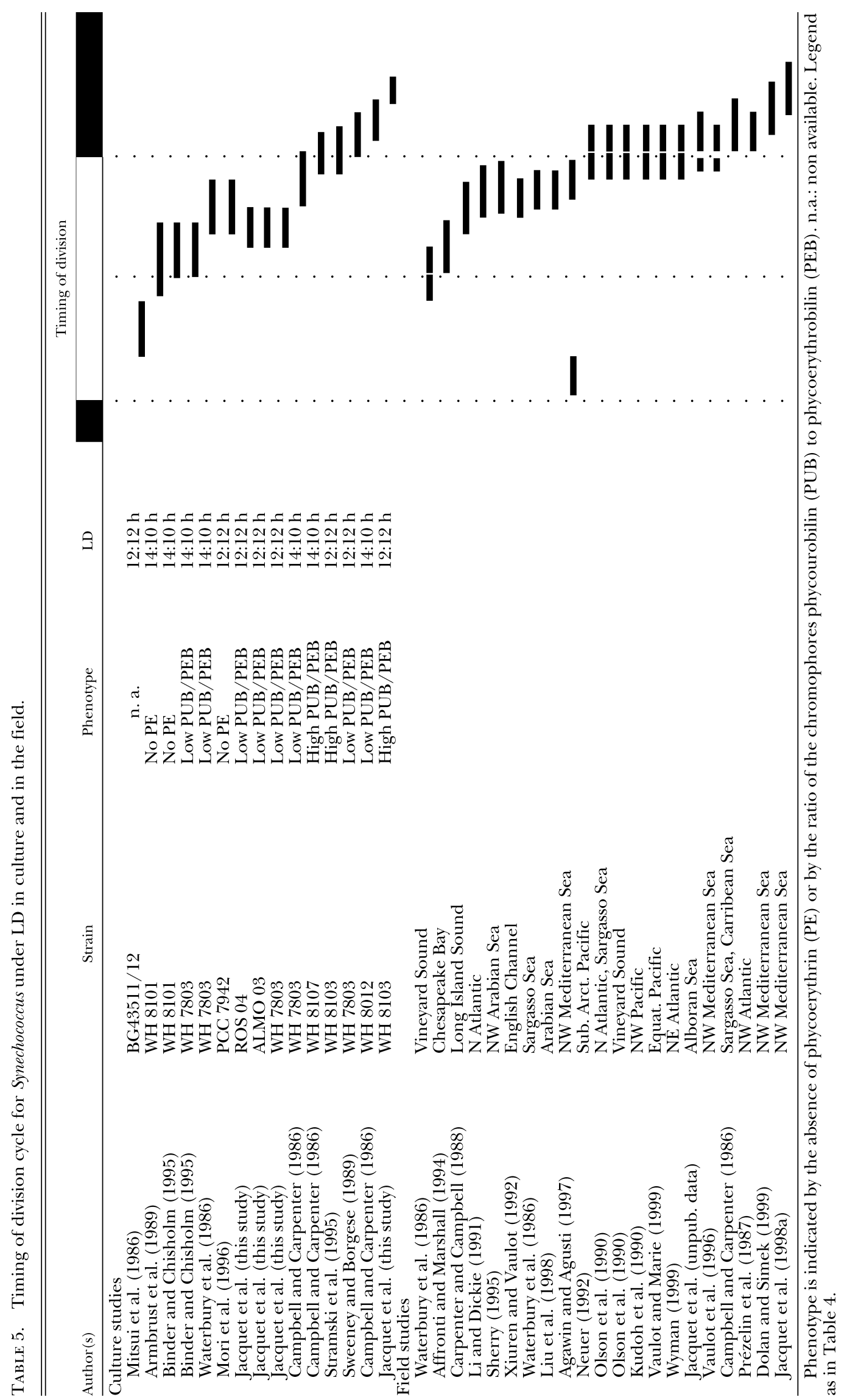


TABLE 6. Timing of division for picoeukaryotes under LD cycle in culture and in the field.

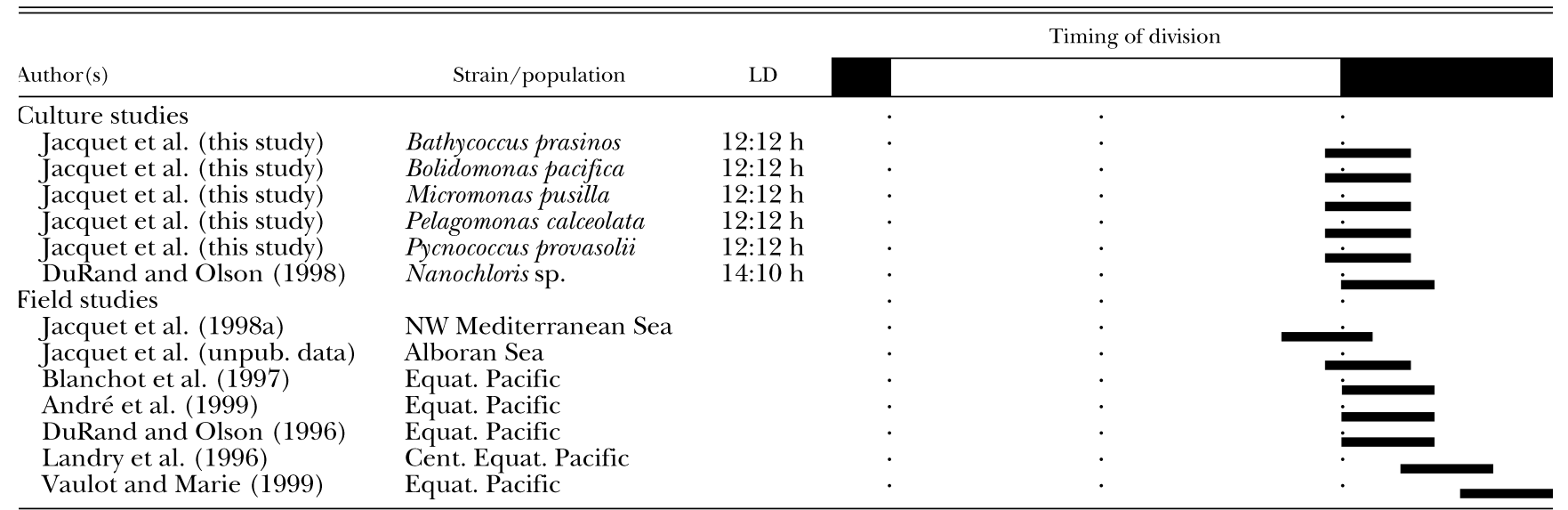

Legend as in Table 4. Except for Blanchot et al. (1997), who focused on a single population of organisms (as estimated by flow cytometry), other studies referred to the whole picoeukaryotic community.

Affronti, L. F. \& Marshall, H. G. 1994. Using frequency of dividing cells in estimating autotrophic picoplankton growth and productivity in the Chesapeake Bay. Hydrobiologia 284:193-203.

Agawin, N. S. R. \& Agusti, S. 1997. Abundance, frequency of dividing cells and growth rates of Synechococcus sp. (cyanobacteria) in the stratified North-western Mediterranean Sea. J. Plank. Res. 19:1599-615.

André, J. M., Navarette, C., Blanchot, J. \& Radenac, M.-H. 1999. Picophytoplankton dynamics in the equatorial Pacific: growth and grazing rates from cytometric counts. J. Geophys. Res. 104:3369-80.

Armbrust, E. V., Bowen, J. D., Olson, R. J. \& Chisholm, S. W. 1989. Effect of light on the cell cycle of a marine Synechococcus strain. Appl. Env. Microbiol. 55:425-33.

Binder, B. J. \& Chisholm, S. W. 1995. Cell cycle regulation in marine Synechococcus sp. strains. Appl. Env. Microbiol. 61:708-17.

Binder, B. J., Chisholm, S. W., Olson, R. J., Frankel, S. L. \& Worden, A. Z. 1996. Dynamics of pico-phytoplankton, ultra-phytoplankton, and bacteria in the Central Equatorial Pacific. Deep-Sea Res. 43:907-31.

Blanchot, J., André, J.-M., Navarette, C. \& Neveux, J. 1997. Picophytoplankton dynamics in the equatorial Pacific: diel cycling from flow-cytometer observations. C. R. Acad. Sci. 320:925-31.

Campbell, L. \& Carpenter, E. J. 1986. Diel patterns of cell division in marine Synechococcus spp.: use of the frequency of dividing cells technique to measure growth rate. Mar. Ecol. Prog. Ser. 32:139-48.

Campbell, L. \& Vaulot, D. 1993. Photosynthetic picoplankton community structure in the subtropical North Pacific Ocean near Hawaii (Station Aloha). Deep-Sea Res. 40:2043-60.

Campbell, L., Landry, M. R., Constantinou, J., Nolla, H. A., Brown, S. L., Liu, H. \& Caron, D. A. 1998. Response of microbial community structure to environmental forcing in the Arabian Sea. Deep-Sea Res. 45:2301-25.

Carpenter, E. J. \& Campbell, L. 1988. Diel patterns of cell division and growth rates of Synechococcus spp. in Long Island Sound. Mar. Ecol. Prog. Ser. 47:179-83.

Carpenter, E. J. \& Chang, J. 1988. Species-specific phytoplankton growth rates via diel DNA synthesis cycles. I. Concept of the method. Mar. Ecol. Prog. Ser. 43:105-11.

Chisholm, S. W. 1981. Temporal patterns of cell division in unicellular algae. Physiological bases of phytoplankton ecology. Can. Bull. Fish. Aquat. Sci. 210:150-81.

Claustre, H., Morel, A., Babin, M., Caillau, C., Marie, D., Marty, J.-C., Taillez, D. \& Vaulot, D. 1999. Variability in particle attenuation and stimulated fluorescence in the tropical and equatorial Pacific: scales, patterns and some biogeochemical implications. J. Geophys. Res. 104:3401-22.
Dolan, J. R. \& Simek, K. 1999. Diel periodicity in Synechococcus and grazing by heterotrophic nanoflagellates: analysis of food vacuole contents. Limnol. Oceanogr. 44:1565-70.

DuRand, M. \& Olson, R. J. 1996. Contributions of phytoplankton light scattering and cell concentration changes to diel variations in beam attenuation in the Equatorial Pacific from flow cytometric measurements of pico-, ultra-, and nanoplankton. Deep-Sea Res. 43:891-906.

DuRand, M. \& Olson, R. J. 1998. Diel patterns in optical properties of the chlorophyte Nanochloris sp.: relating individual-cell to bulk measurements. Limnol. Oceanogr. 43:1107-18.

Edmunds Jr., L. N. \& Adams, K. J. 1981. Clocked cell cycle clocks. Science 211:1002-13.

Gardner, W. D., Chung, S. P., Richardson, M. J. and Walsh, I. D. 1995. The oceanic mixed layer pump. Deep-Sea Res. 42:757-75.

Gough, L. H. 1905. Report of the plankton of the English Channel in 1903. Report of the North Sea Fisheries Investigatory Commission (South Area) 1:325-77.

Ishiura, M., Kutsuna, S., Aoki, S., Iwasaki, H., Anderson, C. R., Tanabe, A., Golden, S. S., Jonhson, C. H. \& Kondo, T. 1998. Expression of a gene cluster $k a i A B C$ as a circadian feedback process in cyanobacteria. Science 281:1429-31.

Jacquet, S., Lennon, J.-F., Marie, D. \& Vaulot, D. 1998a. Picoplankton population dynamics in coastal waters of the N. W. Mediterranean Sea. Limnol. Oceanogr. 43:1916-31.

Jacquet, S., Lennon, J.-F. \& Vaulot, D. 1998b. Application of a compact automatic sea water sampler to high frequency picoplankton studies. Aquat. Microbiol. Ecol.14:309-14.

Jacquet, S., Partensky, F., Marie, D., Casotti, R. \& Vaulot, D. 2001. Cell cycle regulation by light in Prochlorococcus. Appl. Environ. Microbiol. 67:782-90.

Keller, M. D., Selvin, R. C., Clauss, W. \& Guillard, R. L. 1987. Media for the culture of oceanic ultraphytoplankton. J. Phycol. 23:633-8.

Kudoh, S., Kanada, J. \& Takahashi, M. 1990. Specific growth rates and grazing mortality of chroococcoid cyanobacteria Synechococcus spp. in pelagic surface waters in the sea. J. Exp. Mar. Biol. Ecol. 142:201-12.

Landry, M. R., Kirshtein, J. \& Constantinou, J. 1996. Abundances and distributions of picoplankton populations in the central equatorial Pacific from $12^{\circ} \mathrm{N}$ to $12^{\circ} \mathrm{S}, 140^{\circ} \mathrm{W}$. Deep-Sea Res. 43:871-90.

Li, W. K. W. \& Dickie, P. M. 1991. Relationship between the number of dividing and nondividing cells of cyanobacteria in north Atlantic picoplankton. J. Phycol. 27:559-65.

Li, W. K. W., Dickie, P. M., Irwin, B. \& Wood, M. 1992. Biomass of bacteria, cyanobacteria, prochlorophytes and photosynthetic eukaryotes in the Sargasso Sea. Deep-Sea Res. 39:501-19. 
Liu, H., Nolla, H. A. \& Campbell, L. 1997. Prochlorococcus growth rate and contribution to primary production in the Equatorial and Subtropical North Pacific Ocean. Aquat. Microb. Ecol. 12:39-47.

Liu, H., Campbell, L., Landry, M. R., Nolla, H. A., Brown, S. L. \& Constantinou, J. 1998. Prochlorococcus and Synechococcus growth rates and contributions to production in the Arabian Sea during the 1995 southwest and northeast monsoons. Deep-Sea Res. 45:2327-52.

Liu, H. B., Landry, M., Vaulot, D. \& Campbell, L. 1999. Prochlorococcus growth rates in the central equatorial Pacific: an application of the $f_{\max }$ approach. J. Geophys. Res. 104:3391-9.

Liu, Y., Tsinoremas, N. F., Johnson, C. H., Lebedeva, N. V., Golden, S. S., Ishiura, M. \& Kondo, T. 1996. Circadian orchestration of gene expression in cyanobacteria. Gene Dev. 9:1469-78.

Marie, D., Partensky, F., Jacquet, S. \& Vaulot, D. 1997. Enumeration and cell cycle analysis of natural populations of marine picoplankton by flow cytometry using the nucleic acid dye SYBRGreen I. Appl. Env. Microbiol. 63:186-93.

Mitsui, A., Kumazakawa, S., Takahashi, A., Ikemoto, H. Cao, S. \& Arai, T. 1986. Strategy by which unicellular cyanobacteria grow photoautotrophically. Nature 323:720-2.

Moon-van der Staay, S. Y., van der Staay, G. W. M., Guillou, L., Vaulot, D., Claustre, H. \& Medlin, L. K. 2000. Abundance and diversity of prymnesiophytes in the picoplankton community from the equatorial Pacific Ocean inferred from 18S rDNA sequences. Limnol. Oceanogr. 45:98-109.

Mori, T., Binder, B. \& Jonhson, C. H. 1996. Circadian gating of cell division in cyanobacterium growing with average doubling times of less than 24 hours. Proc. Natl. Acad. Sci. USA 93:10183-8.

Nelson, D. M. \& Brand, L. E. 1979. Cell division periodicity in 13 species of marine phytoplankton on a light:dark cycle. J. Phycol. 15:67-75.

Neuer, S. 1992. Growth dynamics of marine Synechococcus spp. in the Gulf of Alaska. Mar. Ecol. Prog. Ser. 83:251-62.

Olson, R. J., Chisholm, S. W., Zettler, E. R. \& Armbrust, E. V. 1990. Pigment, size and distribution of Synechococcus in the North Atlantic and Pacific Ocean. Limnol. Oceanogr. 35:45-8.

Partensky, F., Blanchot, J., Lantoine, F., Neveux, J. \& Marie, D. 1996. Vertical structure of picoplankton at different trophic sites of the subtropical Atlantic Ocean. Deep-Sea Res. 43:1191-213.

Partensky, F., Blanchot, J. \& Vaulot, D. 1999a. Differential distribution and ecology of Prochlorococcus and Synechococcus in oceanic waters: A review. Bull. Inst. Oceanogr. Special Issue 19:457-75.

Potter, D., LaJeunesse, T. C., Sanders, G. W. \& Andersen, R. A. 1997. Convergent evolution masks extensive biodiversity among marine coccoid picoplankton. Biodiv. Conserv. 6:99-107.

Prézelin, B. B., Glover, H. E. \& Campbell, L. 1987. Effects of light intensity and nutrient availability on diel patterns of cell metabolism and growth in populations of Synechococcus spp. Mar. Biol. 95:469-80.

Prézelin, B. B. 1992. Diel periodicity in phytoplankton productivity. Hydrobiologia 238:1-35.

Rippka, R, Coursin, T., Hess, W. R., Lichtlé, C., Scanlan, D. J., Palinska, K. A., Iteman, I., Partensky, F., Tandeau de Marsac, N., Houmard, J. \& Herdman, M. 2000. Prochlorococcus marinus Chisholm et al. 1992, subsp. nov. pastoris, strain PCC 9511, the first axenic chlorophyll a2/b2-containing cyanobacterium (Oxyphotobacteria). Int. J. Syst. Evol. Microbiol. 50:1833-47.
Shalapyonok, A., Olson, R. J. \& Shalapyonok, L. S. 1998. Ultradian growth in the marine planktonic photosynthetic prokaryote Prochlorococcus. Appl. Environ. Microbiol. 64:1066-9.

Sherry, N. D. 1995. Picocyanobacteria in the Arabian Sea During the End of the Winter Monsoon: Diurnal Patterns, Spatial Variability and Division Rates. Thesis, University of Oregon, $62 \mathrm{pp}$.

Siegel, D. A., Dickey, T. D., Washburn, L., Hamilton, M. K. \& Mitchell, B. G. 1989. Optical determination of particulate and production variations in the oligotrophic ocean. Deep-Sea Res. $36: 211-22$

Smayda, T. J. 1975. Phased cell division in natural populations of the marine diatom Ditylum brightwelli and the potential significance of diel phytoplankton behavior in the sea. Deep-Sea Res. 22:151-65.

Spudich, J. L. \& Sager, R. 1980. Regulation of the Chlamydomonas cell cycle by light and dark. J. Cell Biol. 85:136-45.

Stramski, D., Shalapyonok, A. \& Reynolds, R. A. 1995. Optical characterization of the oceanic unicellular cyanobacterium Synechococcus grown under a day-night cycle in natural irradiance. J. Geophys. Res. 100:13295-307.

Sweeney, B. M. \& Borgese, M. B. 1989. A circadian rhythm in cell division in a prokaryote, the cyanobacterium Synechococcus WH 7803. J. Phycol. 25:183-6.

Toledo, G., Palenik, B. \& Brahamsha, B. 1999. Swimming marine Synechococcus strains with widely different photosynthetic pigment ratios form a monophyletic group. Appl. Environ. Microbiol. 65:5247-51.

Vaulot, D., Olson, R. J. \& Chisholm, S. W. 1986. Light and dark control of the cell cycle in two marine phytoplankton species. Exp. Cell Res. 167:38-52.

Vaulot, D. 1989. CytoPC: processing software for flow cytometric data. Signal Noise 2:8

Vaulot, D., Marie, D., Olson, R. J. \& Chisholm, S. W. 1995. Growth of Prochlorococcus, a photosynthetic prokaryote, in the Equatorial Pacific Ocean. Science 268:1480-2.

Vaulot, D., Lebot, N., Marie, D. \& Fukai, E. 1996. Effect of phosphorus on the Synechococcus cell cycle in surface in Mediterranean waters during summer. Appl. Env. Microb. 132:265-74.

Vaulot, D. \& Marie, D. 1999. Diel variability of photosynthetic picoplankton in the equatorial Pacific. J. Geophys. Res. 104:3297-310.

Waterbury, J. B., Watson, S. W., Valois, F. W. \& Franks, D. G. 1986. Biological and ecological characterization of the marine unicellular cyanobacterium Synechococcus. Can. Bull. Fish. Aquat. Sci. 214:71-120.

Wood, A. M., Phinney, D. A. \& Yentsch, C. S. 1998. Water column transparency and the distribution of spectrally distinct forms of phycoerythrin containing organisms. Mar. Ecol. Prog. Ser. 162:25-31.

Wyman, M. 1999. Diel rhythms in ribulose-1,5 biphosphate carboxylase/oxygenase and glutamine synthetase gene expression in a natural population of marine picoplanktonic cyanobacteria (Synechococcus spp.). Appl. Environ. Microbiol. 65:3651-9.

Xiuren, N. \& Vaulot, D. 1992. Estimating Synechococcus spp. growth rates and grazing pressure by heterotrophic nanoplankton in the English Channel and the Celtic Sea. Acta Oceanol. Sin. 11:255-73.

Zubkov, M. V., Sleigh, M. A. \& Burkill, P. H. 2000. Assaying picoplankton distribution by flow cytometry of underway samples collected along a meridional transect across the Atlantic Ocean. Aquat. Microbiol. Ecol. 21:13-20. 